\title{
日本語文字読取装置*
}

\author{
中 野 康 明**
}

Key words: OCR, pattern recognition, Chinese character recognition, Japanese language processing, office automation.

1. は じめ に

文字読取装置 (OCR) は, 電子計算機の入力装置とし て古くから使用されてきたが，近年に至ってパンチレス 化の有力な手段として着目され飛躍的な発展段階を迎え つつある. OCR の真価は, 人間が読める文書をそのまま 読むことができることにある、すなわち，文書を用いた 事務処理形態には長い歴史があり, 事務の機械化に際し て従来の処理の流れを大幅に変更することは好ましくな いが, OCRはこの条件をかなり満たしており, 移行が比 較的に円滑に行くと考えられる.

特に, 昭和 50 年代初期に各社から商品化された端末 OCR は, 小形・低価格で分散処理に適すること, 手書き 仮名文字・英数字が読み取れることなどの特長があり, 日本に和ける OCR 普及の上で重要な位置を占める1).

現在の入出力機器開発の重点は漢字処理に移行してお り, いわゆるオフィスオートメーションでも漢字入力万 式が一つのキーポイントとなっている. 従って, OCR が 入力機器として生き残るためには, 漢字, 特に手書き漢 字を読み取ることが必要であるといら問題意識から，各 所で手書き漢字認識の研究が開始されている.一方では, 読取字種を広げるよりも, 現在の英数仮名文字の範囲で 読取性能を高めることが OCR 発展の原動力であるとい う考方方強い.

本論文では, 現在商品化されている OCRについて, その認識方式や認識性能について解説するとともに, 漢 字認識の可能性について展望してみたい.

\section{2. 文字読取装置の使用形態}

OCR の使用形態として, ターンアラウンド形とデータ ギャザリング形に大別するのが普通である.

ターンアラウンド形は, 使用料金の請求書等を計算機 により印刷し，支払いが完了した時点でその請求書を読 み取って支払いがなされたことを識別する（ファイルの 消し込み）例が典型的なものである. 従って本質的に印 刷文字読取りである. 一般に極めて大量の帳票 (OCR 読 取対象となる各種用紙・伝票を指す OCR 用語) を短期

* 原稿受付 昭和 56 年 4 月 1 日.

** (株)日立製作所（国分寺市東恋ヶ窪 1-280）
間に処理する必要があり, 処理速度が重要視される. 計 算機出力を読み取るので, 読取部分は計算機の内部コー ド表現を使用でき,字種としては数字で斉むことが多い. また読取部分に圥長性（各種のサムチェック）を付与し ておくことで, 信頼性を高くすることが比較的に容易で ある。

データギャザリング形は, 各種の帳票に記入された原 始情報を読み取るものであり, 日本ではタイプライタを 使用することが少ないため手書き文字の読取りが要請さ れる. 日本語処理の観点からは, 手書き漢字を読又取る ことが理想であろらが，現状の技術水準では仮名文字の 読取りが実用化されたばかりであり，使用者側のシステ 么的な処理でカバーしているのが実状である. 現場で発 生する生の情報の入力であるから，あらかじめて長性を 付与することが完全にはできず，誤読が問題となる．特 に, 数字の䛊読に対して使用者は重大視している. 不読 に対しても，その修正方法を工夫して使い勝手を高める 必要がある.

最近は, ターンアラウンド形とデータギャザリング形 の混合形態も多くなってきている. 氏名コードを印字し た出力帳票に，各人の残業時間を記入して，これを計算 機に入力する場合がその例である. 従来, このような使 用法はマークシートを用いることが多かったが，記入ス ペースの節約や, 帳票フォーマットの自由さなどの点で, 今後はますますOCR に移行して行くものと思われる.

文字読取装置はその名の通り文字を読む装置である が, 実用上は文字読取機能だけでなく, 不読文字の修正, ディスプレイ, ホストュンピュータとの接続, 出力媒体, 情報処理機能といった端末装置としての使いやすさや, ドロップアウトカラー, 帳票サイズなど帳票設計上の自 由度も重要であり, 広範な技術が要求される.

\section{3. 手書き文字認識方式}

本章では, 現在実用化されている手書き英数字・仮名 文字を対象とした認識方式について解説する.

図 1 は, OCR に护ける情報処理の流れを一般的に示 したものであるが，本章ではその中の文字認識の部分の みを問題にする. すなわち, 認識系への入力は 1 文字単 位に切り出された文字パターンとする.パターンは通常, 


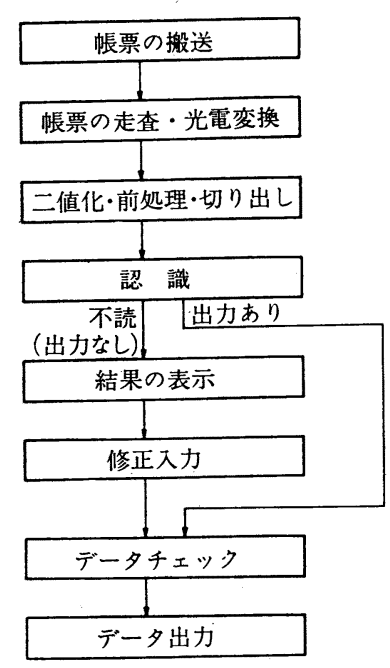

図 1 OCR における情報処理の流れ

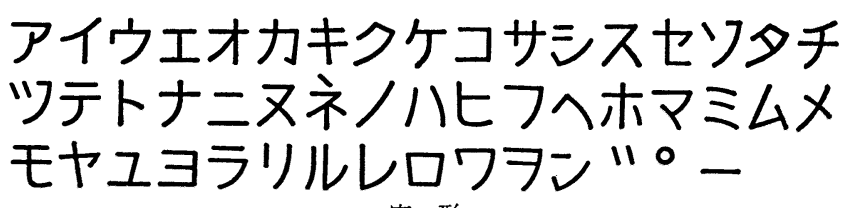

字形

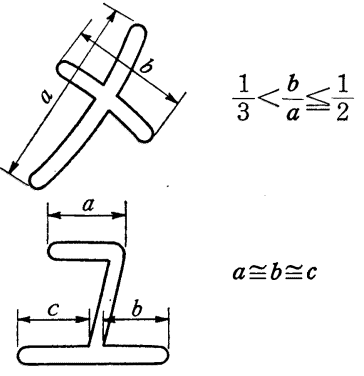

文字に関する注釈の例

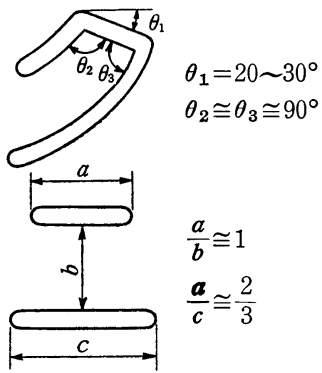

図 2 手書き文字字体 (JIS 規格の例)
$M$ 行 $N$ 列に碁盤目状に分解され, 大きさが $M \times N$ の行 列で表現される. 各碁盤目を文字線（黒）が占めるとさ は 1 , 白地が占めるときは 0 と值を与える. 文字パター ンの例は後出の図 4 の中に示されている.

手書き文字の認識沈いては, 同一文字カテゴリーの 中の多様な変形を無視し (吸収し) 同一視することと, 相異なる文字カテゴリーの間の差異を評価し，誤認識を 避けること, といら二つの相反する要求に応じなければ ならない. しかし, 歴史的に発生状態の異なった文字セ ットを混用するときには，この要求は矛盾したものとな る. 英字の $\mathrm{O}$ と数字の 0 は典型的な例であるが, そのほ かにも「S-5」「ユー2」「ワークー7」など枚挙にいとま がない，混用を持ち出すまでもなく，同じ文字セット， 例えば片仮名の中でも「ッーシ」「リーソーン」なぞ, 個人差によって異なる文字が同じ形状を持っ場合があ る.このような混同を回避するため, OCR 用の基準字体 を定め,これを常用手書き文字字体としている (JIS 案). 図 2 亿常用手書き文字字体の一部を示す2).

この常用手書き文字字体はあくまでも基準であって, 人間がこれを見て手本とするためのものであり，規格で はない，印刷文字の場合の印字品質規格が，字体の細部 までを規定し，ある文字パターンが規格を満たしている かいないかを判定できるのに対し，常用手書き文字字体 は定量的な規定部分もあることはあるが全体としては定 性的な規制に過ざない. 従って, 基準字体があるからと いっても完全な基準ではなく，この基準字体を示したと きに人間がどのようなレスポンスをするかといらことが 問題となる．極端な場合は全く基準を無視して自由な字 体で書く筆者も抢り，これは論外としても，ぞこまでの 変形を許容するかが非常に難しくなってくる．現在市場
に出ている OCR は程度の差はあっても, ある程度の字 形規則違反を許容しているものがほとんどであるが，ど こまでを許容するのが適当か, 文字間での許容範囲のバ ランスは適当かといった問題に対して完全には回答でき ていないと思われる. 入力文字品質が規定できないとす れば, 読取精度も絶対的な意味は持ち得ない. OCR のカ タログに読取精度を記載したものがほとんどないのは, このような事情に基づくものである.

このように多様な変形に対して十分対処し得るように 認識アルゴリズムが考えられている訳であるが，その基 本的な原理として次のように分類される3).

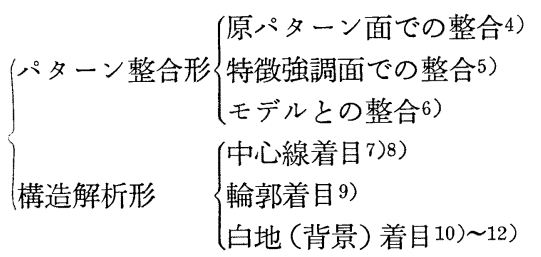

パターン整合形では，入力パターンを標準パターンと 重ね合わせて類似度を求め, 類似度の大きい標準パター ソに対するカテゴリー名を認識結果として出力する. 基 本的には, パターンを 2 次元的にとらえて, 文字を表現 するマトリクス中の各要素の取る値を問題とする.これ に対し, 構造解析形ではパターンの 2 次元的形状を構造 の表現あるいは構造の中のパラメータの差としてとら 光, いわば 1 次元的に構造を表現する. 1 次元的に表現 したときの系列の各要素を表す量を「特徵」と呼ぶ.こ の特徵系列を標準パターンと比較して判定を下す. 昔の 構造解析形アルゴリズムでは, 標準パターンとの照合に 際して完全一致あるいはそれに近い判定基準をとってい たが, 最近はパターンのある程度の変形を許容するため, 


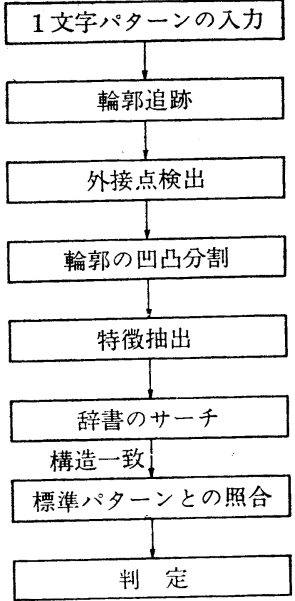

図 3 位相線分法における処理の 流れ

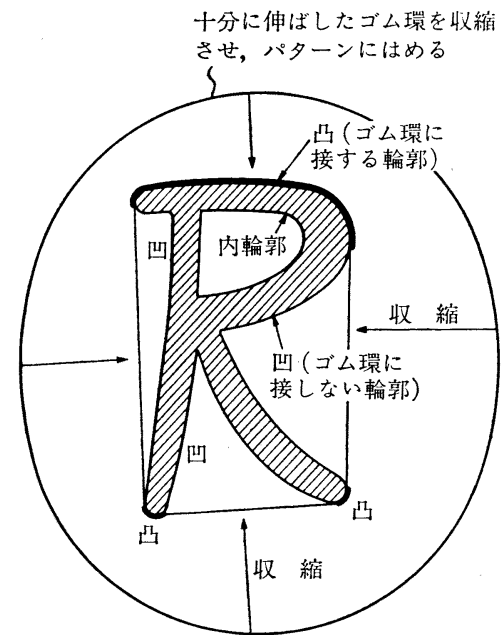

図 4 位相線分法にお打るパターン輪郭の 凹凸分割

柔軟な照合方式が採用されている.

構造解析形の認識手法について説明する99)。構造解析 形は，パターン構造の表現形式として，中心線着目形と 白地着目形とに大きく分かれる．輪郭着目形はこの中間 的な性格を有する，本解説では紙幅の都合で，輪郭解析 形の代表として「位相線分法9 」を取り上げるのにとど めているので，他の手法については参考文献を参照され たい、なお，これらの各種の手法を実際に適用するとき は，ただ一つの方法(原理)で一貫している訳ではなく， 他の方法（原理）と併用することにより, 各手法の短所 を補らのが普通である。

図 3 に位相線分法の処理の流れを示す．この処理の流 れは構造解析法全体にほぼ共通的なるのである。構造解 析法に属する各手法を他の手法から区別するのは，パタ ーンの分割のやり方である. 位相線分法では，パターン の表現形式として輪郭を取り，これを凹線分と凸線分に 分割する．図 4 に示すように，あるパターンの外側に仮 想的なゴム環をはめ,このゴム環に接する部分を凸線分, ゴム環に接しないで内側に入る部分を凹線分とする。

上記のように分割された各線分について特徵を計測す る. 線分内の特徵については, 線分の弧長, 弦長, 深さ, 向き(開方向), 方向ヒストグラム，重心などを求める. 線分間の特徵として，線分間の隣接度をすべての組合わ せについて求める. 図 5 飞一部の特徵の図解を示す.

標準パターンの照合は次のようにする，入力パターン の輪郭数，位相線分数，及びそれらの出現順序と同じ構 造を有する標準パターン（一般には複数個）を探す．同 一構造のものがなければリジェクト（不読）である．同 一構造の標準パターンについては，それぞれについて入 カパターンからの距離を計算する. パターン間の距離 $D$

とは，各特徵ごとに測った距離 $D_{i}$ の加重平均であり, 特徵ごとの距離は入力パターンの特徵の值がその標準パ ターンの該当する特徵についてあらかじめ定めてある上 下限の範囲内なら 0 となり，上下限を冕脱すればその程 度に応じて大きくなるように設定される。すなわち

$$
D=\sum_{i=1}^{L} w_{i} D_{i} \quad(L \text { は特徵数 })
$$

ここで $D_{i}$ は, 特徴ごとの距離で,

$$
D_{i}= \begin{cases}\left|f_{i}-L_{i}\right| & \left(f_{i}<L_{i}\right) \\ 0 & \left(L_{i} \leqq f_{i} \leqq U_{i}\right) \\ \left|U_{i}-f_{i}\right| & \left(U_{i}<f_{i}\right)\end{cases}
$$

各標準パターンについて距離を計算し，距離の最小值 を与える標準パターンの属するカテゴリーを認識結果と する，認識の信頼性を高めるために，距離の最小值があ るしきい值以内にあり，次小值（最小值を除いて次に最 も小さい距離）との差が一定以上であるという条件を更 に付加することもよく行われる. 図 6 亿構造解析法一般 について各種の補強処理を加えた流れを示す。

二つの標準パターンとの距離が極く近いとき，普通り ジェクトにする。これを近接リジェクトと呼ぶ. 近接り ジェクトになるのは，実際に文字パターンが似ていてど ちらとも決定できないとき（従ってリジェクトが正解で あるとき）もあるが, 認識系, 特に特徴抽出系の不備に よることも多い，例壳ば，「メ」と「X」は，各枝を独立 に扱うような認識系では, 特徵量の上下限が完全に重複 し，相互に区別のつかないのが普通である. しかし，こ の二つのカテゴリーは，相隣る枝の長さの差を取れば明 確に区別される．このように，特定のカテゴリ一対に対 してそのぞちらかであるかを判定する処理を二段判定と 呼ぶ (図 6 参照). 二段判定は，1 段の不備を補うもので 


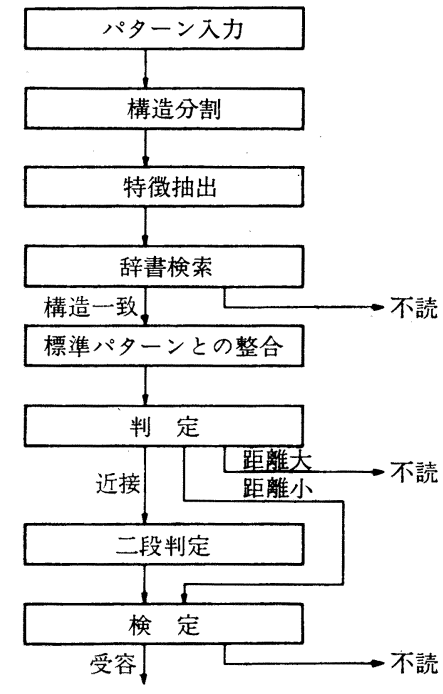

図 6 構造解析法一般における処理の流れ

あるから，最初から必要性が判明している特徵であれば 1 段に組み込几でおいてもよいが，メモリー容量などの 制限から図3のように多段構成にした方が有利なことが 多い. 上記の枝の長さの差を例にとれば，すべての枝の 間の長さの差を特徵量として用意するのは大变であり, 特に必要なときだけ使うようにしている訳である。

図6亿执いて，検定と呼ばれる処理は，入力パターン の認識結果が出た後で真にそのカテゴリーであるといえ るかどらかを検查する部分である，これによって，文字 以外のパターンを誤って認識する危険を減じている.

最後に，手書き文字認識方式の評価方法について述べ る.あるパターンデータの集合について認識実験を行い, 䛊認識率 $E$, 認識拒絶率 (リジェクト率, 不読率) $R$ を 得たとする.この䛊認識とはあくまで人間の認識結果と の一致で評価すべきであり, 書き手の意志との一致では ないことに注意を要する，だれが見ても「ッ」としか読 めない文字パターンがあり，これを書き手は「シ」と書 いたつるりであったとする，認識系がこれを「ッ」と読 むのは正解であり，仮に「シ」と認識したとすればパタ
ーンのラベルとは一致するが誤認識とすべきである。 ま た，人間が見て「シ」だか「ッ」だかわからないといら ものに対して，答を出すのは䛊りとすべきである. しが し, 実際には認識実験で扱ら全サンプルに対して人間の 判定結果を付与するのは至難の業であり, 上に述べたよ らな厳密な評価はまだ十分なされていないのが現状であ る.ただ䛊認識に対して，それが許されるか否かの評価 は行っている. 䛊認識率 $E$ はこのような補正を行ったも のとしょう。よく知られているように, $R$ と $E$ とは一方 を減らそらとすると他方が増すという現象がある。従っ て, 通常に行われているような正読率 $C(=1-(R+E))$ による評価では認識系の良さを十分評価できないことが ある. 実際， $(R+E)$ を最小にしよらと思えば, リジェ クトが出たとき乱数を出してその值によって強制的に答 を出せば必ず $R=0$ になる. $R$ の大半は $E$ になるであろ らがチャンスによって偶然正解になる分だけCは增兄 る.このような愚かしい結果を避けるため， $E$ に対して ペナルティをかけて評価することを提案したい。すなわ ち, 認識系の性能 (悪さ) として, $(R+k E)$ なる尺度を 用いる. $k>1$ であるが, $k$ の值はアプリケーションを考 慮して決める必要がある。

\section{4. 漢字認識装置}

始めに述べたように, 漢字処理システムの普及に伴い 漢字認識の必要がますます痛感されるようになってき た.このことは古くから予見されていたことでありそ の一つの突破口として単一字体印刷漢字認識が研究され てきた. このテーマは昭和 48 年に大型プロジェクト「パ ターン情報システムの研究開発」の一サブシステムとし て取り上げられ，この大型プロジェクト及びこれに前後 する研究により試作機が作られるまでに至っている。

表 1 亿, 印刷漢字認識装置試作機の性能を示す. 印刷 漢字認識の場合, 読取対象が OCR 読取りを意識して印 刷されたものではないことが多く，印刷文字とはいって もターンアラウンド形ではなくデータギャザリング形の 応用になる. 大型プロジェクトで開発されたものは，特

表 1 印刷漢字 OCR 試作機の性能

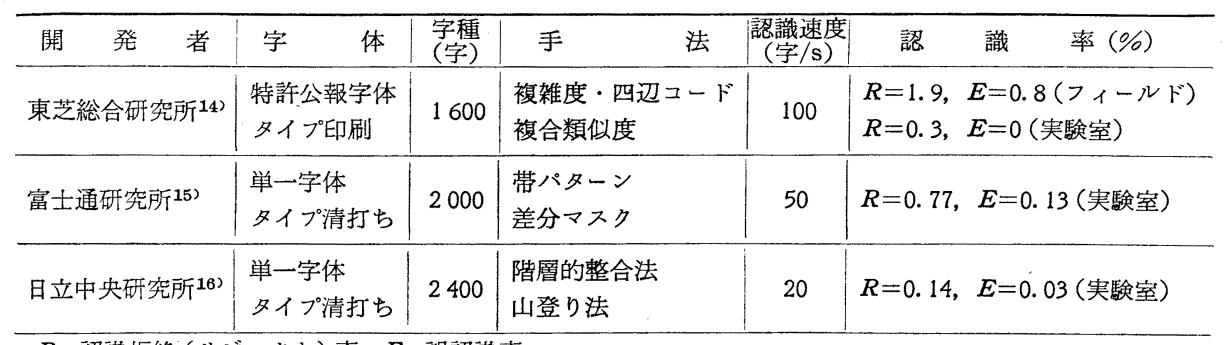

$R:$ 認識拒絶 (リジェクト) 率, $E:$ 誤認識率 
許公報読取りを想定対象としているが，フィールドデー 夕に適用したときの認識結果に漢字認識の困難性が浮き 彫りにされている.すなわち, これらの試作機では読取 字種として約 2000 字程度を設定しているが，外字 (対 象外字種）が入ってきたときに誤読を生じやすいことが ある.また，実サンプルでは単一字体の制約は守られず， 印刷所が異なれば字体が变化し，同一印刷所であっても 活字母型の摩耗による母型更新時に字体が変わるなどの 理由によって多種字体認識を余儀なくされる。このよう な認識性能の低下に対して, 文脈情報の利用により改善 が試みられているが，印刷漢字よりも更に困難な手書き 漢字認識に执いても言語情報の利用は不可欠であること を示唆している。

他の試作機に打いては，和文タイプによる事務文書の 読取りを想定用途としており，その前提として印字字体 の規格の設定を条件としている. 単一字体の条件が満足 されれば認識精度はかなり高くできるが，実際の使用者 に対して制定した字体の活字の使用を要請できるか疑問 がある.また，手動タイプでは印字品質の管理も問題と なる。

漢字認識の場合には不読文字の入力も問題である. 英 数字程度の場合には, 不読文字パターンを表示し, オペ レータがその文字キーを打鍵するのが通常の方法である が，漢字の場合は漢字入力自体が一つの技術課題であ る. また, 入力速度も問題であって，1字の入力に要す る時間を $T(\mathrm{~s})$ とし, 認識時間を $\tau(\mathrm{s})$, 認識拒絶率を $R$ とすると, $R T<\tau$ でないと打鍵入力待らのため認識装置 が待たされることになる. 実際には, $R$ も $T$ む小さくす るには限界があるので, 非常に高速の認識装置を作って も意味がないことになる。

以上，単一字体に限定すると実用性㠜問があること を述べた. 複数字体印刷漢字認読の研究も行われている が19), 完全な複数字体印刷文字認識は手書き文字認識と 同程度の困難性があると考光られ，実用上は手書き漢字 認識の必要性の方がはるかに高いことはいうまでもな い. 手書き漢字認識は，いくつかの先駆的な研究17)18) を除き，最近まであまり研究されていなかったが，この 1,2 年の間に各所で研究が開始された20). 研究開始の手 掛かりとして，漢字の大分類（候補文字の限定）をねら うものが多いようであり, 研究遂行上の一つの戦略とし て妥当な方向である. しかし, 最終的な認識法の見通し を付けて扔かないと, 単に分類に終わって成果につなが らない恐れもあり，やはり認識方式の優劣が問題であろ 万.

現在のところ，手書き漢字の变形を考えると構造解析
法では辞書が有限の大きさ（あるいは経済性から見た実 現範囲）に収まらない心配があり，一方類似度法では果 たしてどこまで行けるか見通しがつかないといった状況 にあり，決定的な解答の端緒すら見い出せていないと考 える。

\section{5. む す び}

以上，文字読取装置の現状と展望を簡単に述べた. OCR の良さ，すなわち人間が読む文書をそのまま機械 も読むといら点を十分理解され OCR 発展の一助となれ ば幸いである。

\section{参 考 文 献}

1）下矢吉孝ほか：分散形 OCR T 550/30, 日立評論 (1978).

2) JIS C 6255: 光学式文字認識のための手書き文字（数 字).

JIS C 6254：光学式文字認識のための手書き文字 (片仮 名).

3）中田和男編：パターン認識とその応用, コロナ社(1978).

4）吉沢正彬ほか: マッチング法による高速手書カナ OCR, 電子通信学会全国大会講演論文集（1980） 1330.

5) 安田道夫ほか: 文字認識のための相関法の一改良, 電子 通信学会論文誌 (D), 62-D, 3 (1980) 217 .

6) 迫江博昭: Rubber String Matching 法による手書き文 字認識, 電子通信学会研究会資料, PRL 74-20 (1974).

7) Y. Fujimoto et al. : Recognition of Handprinted Characters by Nonlinear Elastic Matching, Proc. 3rd IJCPR, (1976).

8）宮崎祀夫ほか：折線近似による手書きカタカナ認識, 電 子通信学会研究会資料, PRL 74-62 (1974).

9）山本和彦ほか：手書きカタカナ文字々数字の機械認識, 電子通信学会論文誌 (D)， 59，6 (1976) 414

10）森 晃徳ほか：場の効果法による特徴抽出，電子通信学 会論文誌(D)， 57-D， 5 (1974）308.

11）吉田真澄：全手書き文字の認識システム, 情報処理, 17, 7 (1976) 595.

12) K. Komori et al. : A Feature Concentration Method for Character Recognition, Proc. IFIP Congr. '77, (1977) 29.

13）門田彰三：非線形マッチングによる手書英数字の認識, 電子通信学会全国大会講演論文集（1975） 1229.

14）坂井邦夫ほか：漢字 OCR のためのシミュレーションシ ステム, 情報処理, 17, 7 (1976) 587 .

15) T. Fujita et al. : Kanji Character Recognition System, Fujitsu STJ, 13, 3, (1977) 23.

16）北爪吉明ほか：印刷漢字認識装置, 電子通信学会全国大 会講演論文集（1979） 1339 .

17）吉田 実：手書漢字認識による住所の読取, 電子通信学 会全国大会講演論文集, S 10-6 (1977).

18）小川秀夫ほか: 漢字の階層表現とその認識, 電子通信学 会論文誌 (D)， 57-D (1974） 700 .

19）梅田三千雄ほか：マルチフォント印刷漢字認識のための 粗分類, 電子通信学会論文誌 (D), 62-D (1979) 758 .

20）萩田紀博ほか: 二つの概形特徵を用いた手書漢字の分 類，電子通信学会論文誌，J 63-D（1980） 1096.

21) 斉藤泰一ほか: 手書文字データベースの解析 (IV), 電 子技術総合研究所笨報, 44, 4 (1980) 1 . 